\title{
BARBARA RODZIEWICZ
}

\section{„Gdybym był bogaty...” Bogactwo jako jednostka aksjotyczna w świadomości językowej Polaków, Rosjan i Niemców}

Pojęcie bogactwa nie jest jednoznaczne i homogeniczne, ponieważ jest uwarunkowane przynależnością do określonego kręgu kulturowego i tradycją społeczno-religijną. Bogactwo materialne, w potocznej świadomości najczęściej uznawane za wyznacznik dobrobytu i majętności, stanowi zaledwie jeden z jego przejawów.

Stosunek do dóbr materialnych zmieniał się na przestrzeni dziejów, nigdy jednak bogacenie się nie było uznawane w swej istocie za zło, mimo że odmienne interpretacje kwestii bogactwa nie są odosobnione (choćby całkowita negacja i chęć uniezależnienia się od jakiejkolwiek jego formy, na przykład we wczesnośredniowiecznym nauczaniu waldensów) ${ }^{1}$. Zarówno w filozofii antycznej, jak i w późniejszej refleksji na temat bogactwa przeważa przekonanie, iż prawo do posiadania dóbr należy rozumieć jako jedno z fundamentalnych praw przysługujących jednostce. Wyraźnie zaznacza się również idea zachowania wolności wobec dóbr materialnych, a także tendencja do ukazywania dobrobytu w aspekcie wspólnego dobra. Bogactwo stanowi wartość (służebną, instrumentalną), o ile jest właściwie użytkowane, jest konsekwencją pracy, owocem trudu, a nie jedynie celem samym w sobie; w przeciwnym razie jego wymiar aksjotyczny staje się wątpliwy, a hierarchia wartości — zaburzona.

W niniejszym tekście spróbuję przybliżyć współczesne sposoby rozumienia bogactwa przez przedstawicieli trzech zbiorowości językowych - Polaków, Rosjan i Niemców. Czym jest bogactwo? Co się na nie składa? Co przesądza o tym, że ktoś jest bogaty, jakie są źródła i sposoby osiągania bogactwa? Czy bogactwo

${ }^{1}$ P. Siek, Bogactwo. Przyczynek do katolickiego ujęcia tej kategorii, „Annales. Etyka w Życiu Gospodarczym"18, 2015, nr 2, s. 49. 
czyni człowieka godnym szacunku, czy wręcz przeciwnie — bogacz zasługuje na pogardę? Czy bogactwo jest wartością, do której należy lub warto dążyć, a jeśli tak, to dlaczego? Odpowiedzi na te pytania, a zarazem ustalenie treściowego zasobu pojęcia (wraz z całym jego pokaźnym obszarem konotacji i ocen) funkcjonującego w świadomości użytkowników języka polskiego, rosyjskiego i niemieckiego było jednym z celów zakrojonego na masową skalę eksperymentu językowego.

W badaniach zastosowałam znaną od czasów Francisa Galtona metodę swobodnych skojarzeń słownych ${ }^{2}$, polegającą na podaniu przez respondenta skojarzenia werbalnego na stymulant, to jest pierwszego słowa lub wyrażenia, które mu przychodzi na myśl po usłyszeniu lub przeczytaniu wyrazu-bodźca. Eksperyment asocjacyjny, w wyniku którego zebrałam materiał do niniejszego opracowania objął grupę 1500 osób - 500 respondentów polskojęzycznych, 500 respondentów rosyjskojęzycznych i 500 respondentów niemieckojęzycznych, w równej mierze kobiet i mężczyzn. W teście wzięli udział studenci w wieku 18-25 lat, kształcący się na studiach stacjonarnych różnych kierunków w ośrodkach akademickich w Polsce, Rosji i Niemczech ${ }^{3}$.

Obrana przeze mnie metoda eksperymentalna wydaje się uzasadniona w kontekście naukowo uwarunkowanych i szeroko omawianych w literaturze przesłanek przyjmujących za punkt wyjścia założenie, że wszystkie pojęcia i słowa języka, którym posługuje się człowiek, przechowywane są w językowym obszarze jego świadomości (świadomości abstrakcyjnej) w formie całościowej pojęciowo-werbalnej sieci, „symbolicznej reprezentacji otoczenia"4. Żadne pojęcie ani słowo leksykonu umysłowego nie funkcjonuje z osobna; przeciwnie - każde wchodzi w logiczne, spójne i uhierarchizowane związki z innymi słowami i pojęciami. Евгений Тарасов, przedstawiciel moskiewskiej szkoły psycholingwistycznej, definiuje ten „całokształt poziomów świadomości, formowanych i uzewnętrznianych za pomocą środków językowych: słów, związków wyrazowych, zdań, tekstów i pól asocjacyjnych" jako świadomość językową ${ }^{5}$. Świadomość językowa jest z kolei częścią większej całości, tak zwanej świadomości etnokulturowej6. Алла Гурочкина w taki sposób precyzuje to pojęcie: „Этнокультурное сознание - результат отражения и восприятия образа мира в соответствии с особой

2 F. Galton, Psychometric Experiments, „Brain. A Journal of Neurology” 1879, nr 2, s. 149 162.

${ }^{3}$ Wspomniany eksperyment stanowił podstawę szerokich badań nad systemem wartości współczesnych młodych Polaków, Rosjan i Niemców. Metodologię oraz całość wyników omawiam w monografii Wartości. Polacy. Rosjanie. Niemcy, Szczecin 2014.

4 J. Anusiewicz, Lingwistyka kulturowa. Zarys problematyki, Wrocław 1995, s. 29.

5 Е.Ф. Тарасов, Актуальные проблемь анализа языкового сознания, [w:] Языковое сознание и образ мира, red. Н.В. Уфимцева, Москва 2000, s. 26.

${ }^{6}$ Ю.Н. Караулов, Ю.Н. Филиппович, Лингвокультурное сознание русской языковой личности. Моделирование состояния и функиионирования, Москва 2009, s. 7-14. 
сеткой ценностно-смысловых координат, представляющих содержательные контуры той или иной национальной культуры"7.

Co szczególnie ciekawe, właśnie badania asocjacyjne jasno wykazują, iż na szablony skojarzeniowe w wysokim stopniu wpływają czynniki kulturowe. Hipotezę o kulturowym ukierunkowaniu werbalizacji pojęć używanych podczas eksperymentu asocjacyjnego w charakterze wyrazów hasłowych potwierdzają językoznawcy podejmujący w ostatnim czasie studia międzykulturowe z wykorzystaniem testów skojarzeniowych.

Przejdę zatem do wyników testu asocjacji werbalnych i przeanalizuję strukturę sieci skojarzeniowej powstałej wokół słów-bodźców BOGACTWO/БОГATCTBO/REICHTUM. Pozyskany materiał badawczy to 523 nieukierunkowane swobodne reakcje-skojarzenia na przytoczone wyrazy hasłowe: 150 asocjatów polskojęzycznych, 168 rosyjskojęzycznych i 205 niemieckojęzycznych.

W zdecydowanej większości pozyskanych reakcji zawierają się pierwotne składniki leksykalne referowanego pojęcia. Skojarzenia ankietowanych na słowo-bodziec mają wyraźne umocowanie definicyjne. Bogactwo konceptualizowane jest przede wszystkim w wymiarze materialnym. Główną konstytuentę treściową pojęcia stanowią sformułowane wprost przy pomocy rozmaitych pod względem wyrażenia, z reguły spójnych w planie semantyki, odpowiedzi w postaci leksemów nazywających pieniądze.

Najwięcej odpowiedzi w tym kontekście przytaczają badani Polacy (44\% ogółu ujęzykowień); porównaj na przykład: pieniądze (202 wskazania — 40,4\%), kasa (12 wskazań — 2,4\%), dolary (3 reakcje — 0,6\%), forsa (1 reakcja — 0,2\%). $\mathrm{O}$ tym, iż posiadanie pieniędzy jest głównym przejawem bogactwa, przekonani są również młodzi Niemcy i Rosjanie, jakkolwiek liczba obcojęzycznych respondentów podzielających to przeświadczenie jest prawie dwukrotnie niższa niż liczba ankietowanych Polaków; porównaj na przykład: asocjaty rosyjskojęzyczne деньги (120 wskazań - 24\%), монеть (3 reakcje — 0,6\%), доллары (1 reakcja — 0,2\%); asocjaty niemieckojęzyczne — Geld (145 wskazań — 28,1\%).

W wymiarze materialnym mieszczą się także odpowiedzi pośrednio wskazujące na związek bogactwa z pieniędzmi, ujęzykowione za pomocą słów i wyrażeń odnoszących się do szerzej pojmowanej sfery finansowej. W świadomości młodych respondentów, zwłaszcza polsko- i niemieckojęzycznych, utrwaliły się przede wszystkim nazwy instytucji i oferowanych przez nie produktów finansowych; porównaj na przykład: polskie — bank (9 wskazań — 1,8\%), konto (1 reakcja - 0,2\%); niemieckie — Bank (4 reakcje — 0,8\%), Aktien (1 reakcja - 0,2\%), Anlage (1 reakcja — 0,2\%), Kreditkarte (1 reakcja — 0,2\%), volles Konto (1 reakcja — 0,2\%), Zinsen (1 reakcja — 0,2\%); rosyjskie - сбережения (1 reakcja - 0,2\%), счёт в банке (1 reakcja - 0,2\%).

${ }^{7}$ А.Г. Гурочкина, Этнокультура и языковое сознание, [w:] Филология и культура: Материаль ІІІ Международной научной конференции 16-18 мая, 2001, cz. 3, Тамбов 2001, s. 122-123. 
Rosjanie tworzą wokół pojęcia bogactwa dość wyraźną sieć asocjacyjną (ponad $10 \%$ wszystkich skojarzeń), w której centrum sytuuje się tradycyjny symbol zamożności — złoto. Polacy ponad trzykrotnie rzadziej niż ich wschodnioeuropejscy rówieśnicy przytaczają ekwiwalentne słowo. Pojedyncze odniesienia do tego szlachetnego kruszcu odnajdujemy $\mathrm{w}$ asocjatach przytaczanych przez przedstawicieli społeczności zachodnioeuropejskiej (poniżej 1\% skojarzeń); porównaj na przykład: odpowiedzi rosyjskie — золото (53 wskazania — 10,6\%); odpowiedzi polskie zloto (16 wskazań - 3,2\%); odpowiedzi niemieckie — Gold (3 reakcje - 0,6\%).

W tradycyjny kontekst kulturowy wpisują się licznie przytaczane w odpowiedziach nazwy konkretnych desygnatów materialnych. Uczestnicy eksperymentu wskazują na zasób dóbr i same dobra rzeczowe, których posiadanie postrzegane jest jako zewnętrzny przejaw bogactwa; porównaj na przykład: asocjaty polskie - majątek (17 wskazań - 3,4\%), willa (4 reakcje - 0,8\%), dobra materialne (2 reakcje $-0,4 \%)$, ferrari ( 2 reakcje $-0,4 \%)$, pałac $(2$ reakcje $-0,4 \%)$, samochód (2 reakcje - 0,4\%), bizuteria (1 reakcja - 0,2\%), duży dom (1 reakcja $-0,2 \%)$, jacht $(1$ reakcja - 0,2\%); asocjaty rosyjskie - дом (6 reakcji - 1,2\%), особняк (2 reakcje - 0,4\%), автомобиль (1 reakcja - 0,2\%), алмазы (1 reakcja - $0,2 \%$ ); asocjaty niemieckie — Vermögen (6 reakcji - 1,2\%), Haus (5 reakcji - 1\%), Auto (2 reakcje - 0,4\%), Jacht (1 reakcja - 0,2\%), materieller Besitz (1 reakcja - 0,2\%), Schloss (1 reakcja - 0,2\%).

Kilku studentów zza zachodniej granicy eksponuje również pojęcie własności i posiadania w ogóle: Besitz (1 reakcja - 0,2\%), Besitztum (1 reakcja - 0,2\%), Eigentum (1 reakcja - 0,2\%).

Bogactwo materialne utrwaliło się w kolektywnej pamięci badanych także jako gwarancja wyższego/wysokiego standardu życia i związanego z nim poziomu konsumpcji. Ten aspekt konceptu omawianego pojęcia akcentują przede wszystkim młodzi Niemcy (ponad 5\% respondentów); porównaj na przykład: skojarzenia niemieckie - Luxus (16 wskazań - 3,2\%), erfolgreiches Leben (1 reakcja - 0,2\%), guten Lebensstil haben (1 reakcja - 0,2\%), ist zu haben was man will (1 reakcja - 0,2\%), leicht leben (1 reakcja - 0,2\%), prächtig (1 reakcja - 0,2\%), Protz (1 reakcja - 0,2\%), üppig (1 reakcja - 0,2\%), Voraussetzung für ein gutes Leben (1 reakcja - 0,2\%); skojarzenia polskie - luksus (5 reakcji - 1\%), zbytek (2 reakcje - 0,4\%), tatwe życie (1 reakcja $-0,2 \%)$, przepych (1 reakcja - 0,2\%), przyjemne zycie (1 reakcja $-0,2 \%)$, ułatwienie $w$ życiu (1 reakcja - 0,2\%); skojarzenia rosyjskie — роскошь (7 reakcji - 1,4\%), комфорт (4 reakcje - 0,8\%), удобство (2 reakcje $0,4 \%)$, изобилие (1 reakcja - 0,2\%), развлечения (1 reakcja - 0,2\%).

Kolejna liczebnie duża grupa asocjatów sytuuje się na płaszczyźnie pozamaterialnej - w sferze duchowej. Bogactwo utożsamiane jest tu $\mathrm{z}$ bogactwem wewnętrznym, wartościami etycznymi i poznawczymi. Skojarzenia tej sfery to jednocześnie eksplikowane implicite elementy wartościujące analizowanego konceptu, przy czym ewaluacja ma ukierunkowanie zdecydowanie dodatnie. Tę część 
zasobu treściowego bogactwa uwypuklają zwłaszcza Rosjanie (ponad 8\% ogółu skojarzeń), nieco niższym poziomem frekwencji charakteryzują się reakcje przedstawicieli pozostałych ankietowanych społeczności; porównaj: asocjaty rosyjskie - душа (18 wskazań — 3,6\%), духовное (4 reakcje — 0,8\%), знания (2 reakcje — 0,4\%), мудрость (2 reakcje — 0,4\%), внутреннего мира (1 reakcja 0,2\%), внутренний мир (1 reakcja - 0,2\%), добро (1 reakcja - 0,2\%), добро и честность (1 reakcja — 0,2\%), духа (1 reakcja — 0,2\%), духовное развитие (1 reakcja - 0,2\%), духовность (1 reakcja - 0,2\%), моральное (1 reakcja 0,2\%), наполненое сердие (1 reakcja — 0,2\%), правда (1 reakcja - 0,2\%); asocjaty polskie — wiedza (2 reakcje — 0,4\%), madrość (2 reakcje - 0,4\%), duch (1 reakcja - 0,2\%), duchowe (1 reakcja - 0,2\%), uczciwość (1 reakcja - 0,2\%), wnętrze człowieka (1 reakcja — 0,2\%); asocjaty niemieckie — Wissen (4 reakcje - 0,8\%), des Geistes (1 reakcja - 0,2\%), geistig (1 reakcja - 0,2\%), geistiger Reichtum (1 reakcja — 0,2\%), Wahrheit (1 reakcja - 0,2\%).

Do powyższej grupy z pewnością należy zaliczyć również reakcje niemieckojęzyczne negujące utrwalony definicyjnie profil bogactwa: hat nichts mit Geld zu tun (1 reakcja — 0,2\%), kein Geld (1 reakcja - 0,2\%), materieller ist vergänglich (1 reakcja - 0,2\%), mehr als Geld (1 reakcja - 0,2\%), nicht finanzieller (1 reakcja $-0,2 \%)$.

Konceptualizacja bogactwa w wymiarze pozamaterialnym dokonuje się w świadomości językowej ankietowanych także w powiązaniu z wieloma innymi wartościami. Poza wspomnianymi już poznawczymi i etycznymi w referowane pojęcie wpisują się wartości wspólnotowe, witalne, odczuciowe i prestiżowe.

Utożsamiane z bytami aksjologicznymi bogactwo waloryzowane jest pozytywnie. Polacy upatrują w bogactwie przede wszystkim źródła pozytywnych emocji, dla Rosjan i Niemców najistotniejszy jest jego wymiar prestiżowy. Bogactwo w ujęciu aksjotycznym odnośnie do poszczególnych wartości ilustrują poniższe reakcje:

1. Wartości wspólnotowe: polskie — rodzina (3 reakcje - 0,6\%), przyjaciele (1 reakcja - 0,2\%); rosyjskie - семья (10 wskazań - 2\%), друзья (3 reakcje - 0,6\%), дети (1 reakcja — 0,2\%); niemieckie — Familie (5 reakcji — 1\%), Familie und Freunde (1 reakcja — 0,2\%), Freunde (1 reakcja - 0,2\%).

2. Wartości witalne: polskie — zdrowie (2 reakcje — 0,4\%), zycie (1 reakcja - $0,2 \%)$; rosyjskie — здоровье (4 reakcje — 0,8\%), жизнь (1 reakcja - 0,2\%); niemieckie — Gesundheit (6 reakcji — 1,2\%), an Gesundheit (1 reakcja - 0,2\%).

3. Wartości odczuciowe: polskie — szczesście ( 7 reakcji - 1,4\%), w doznaniach (1 reakcja - 0,2\%); rosyjskie — cчастье ( 8 reakcji - 1,6\%), любовь ( 2 reakcje — 0,4\%), радость (2 reakcje — 0,4\%), удовольствие (1 reakcja $0,2 \%)$; niemieckie — Liebe (2 reakcje — 0,4\%), Spaß (2 reakcje — 0,4\%), Glück (1 reakcja - 0,2\%), Lebensfreude (1 reakcja - 0,2\%).

4. Wartości prestiżowe: polskie — władza (3 reakcje - 0,6\%), stawa (3 reakcje — 0,6\%), sukces (3 reakcje — 0,6\%); rosyjskie — власть (24 wskazania — 
4,8\%), усnех (4 reakcje - 0,8\%), слава (1 reakcja - 0,2\%); niemieckie - Macht (18 wskazań - 3,6\%), Erfolg (7 reakcji - 1,4\%), Position (1 reakcja - 0,2\%).

Pozostałe asocjaty eksponujące implicite pozytywny stosunek respondentów do referowanego pojęcia nawiązują w swej treści do sfery potrzeb. Ankietowani, zwłaszcza rosyjsko- i niemieckojęzyczni, konstatują związek bogactwa z podstawowymi potrzebami psychogennymi - wolnością, bezpieczeństwem i stabilnością/stabilizacją. Młodzi Niemcy i Rosjanie w pierwszej kolejności podkreślają w tym kontekście możliwość zaspokojenia potrzeby wolności, tworząc równocześnie wyraźne i kwantytatywnie silne sieci werbalno-asocjacyjne, których głównym ogniwem czynią bezpieczeństwo. Ich polskojęzyczni rówieśnicy sygnalizują jedynie - najczęściej skojarzeniami jednostkowymi — potrzeby bezpieczeństwa, spokoju i wolności. Oto typowe odpowiedzi: polskie - spokój (4 reakcje - 0,8\%), bezpieczeństwo ( 1 reakcja - 0,2\%), niezależność (1 reakcja - 0,2\%), stabilizacja (1 reakcja — 0,2\%), wolność (1 reakcja - 0,2\%); rosyjskie - свобода (20 wskazań - 4\%), обеспеченность (4 reakcje - 0,8\%), безопасность (1 reakcja - 0,2\%), стабильность (1 reakcja - 0,2\%); niemieckie - Freiheit (25 wskazań - 5\%), Sicherheit (11 wskazań - 2,2\%), Unabhängigkeit (1 reakcja - 0,2\%).

Akceptację bogactwa respondenci wyrażają również wprost przy pomocy leksemów prymarnie wartościujących, aczkolwiek jawna ewaluacja znajduje odzwierciedlenie w niewielkim odsetku ujęzykowień. Najbardziej charakterystyczne werbalizacje to: polskie — przydatne ( 2 reakcje — 0,4\%), istotne (1 reakcja $0,2 \%)$; rosyjskie - хорошо (5 reakcji - 1\%), благо (1 reakcja - 0,2\%), здорово ( 1 reakcja - 0,2\%), чудесно (1 reakcja — 0,2\%); niemieckie — ist gut (1 reakcja $-0,2 \%)$, ist schön (1 reakcja - 0,2\%), wichtig (1 reakcja - 0,2\%).

Waloryzacja bogactwa nie ma charakteru jednobiegunowego. Oceniane jest ono również negatywnie, wprost lub - częściej - z wykorzystaniem środków wtórnie wartościujących. Wartościowanie ukierunkowane in minus charakteryzuje jednak znacznie niższy poziom częstości ujęzykowień, niż ma to miejsce w wypadku pozytywnej ewaluacji bogactwa. Najwięcej ocen krytycznych formułują Niemcy, którzy są przekonani, iż bogactwo nie stanowi o sensie życia człowieka, wręcz przeciwnie - czyni go nieszczęśliwym; porównaj na przykład: macht nicht glücklich (12 wskazań - 2,4\%), uwichtig (9 wskazań - 1,8\%), ist nicht alles (3 reakcje - 0,6\%), Geld macht nicht glücklich (1 reakcja - 0,2\%). Współankietowani Polacy i Rosjanie nie wyrażają aż tak wyraźnie dezaprobaty, co poświadczają mniej liczne, w głównej mierze, pojedyncze skojarzenia; porównaj na przykład: asocjaty polskie — nieistotne ( 2 reakcje - $0,4 \%)$, bezsens ( 1 reakcja - 0,2\%), mało ważne (1 reakcja - 0,2\%); asocjaty rosyjskie - не всегда хорошо (1 reakcja - 0,2\%), не главное (1 reakcja - 0,2\%), не самое важное (1 reakcja - 0,2\%).

Waloryzacja negatywna dokonuje się także w kontekście etycznym. Na potencjalne zagrożenia wypływające z posiadania bogactwa zwracali uwagę już staro- 
żytni myśliciele, między innymi Platon, który wiązał nadmierne wysiłki jednostki ukierunkowane na zdobycie dóbr materialnych z jej deprawacją i przeszkodą na drodze do osiągnięcia doskonałości moralnej. Badana młodzież wyraża swój stosunek do bogactwa oraz pośrednio do ludzi zamożnych, transponując niejako myśl platońską, i konotuje referowane pojęcie z oznakami właśnie moralnej degradacji, egoizmu, sprzeniewierzania się ogólnie obowiązującym zasadom etycznym; porównaj na przykład: odpowiedzi polskie $-\operatorname{snobizm~(4~reakcje~}-0,8 \%)$, materializm (2 reakcje $-0,4 \%), z d r a d a(2$ reakcje $-0,4 \%)$, zło (2 reakcje $-0,4 \%)$, lenistwo (1 reakcja - 0,2\%), próżność (1 reakcja - 0,2\%); odpowiedzi rosyjskie - жадность (4 reakcje - 0,8\%), зло (3 reakcje — 0,6\%), ложь (3 reakcje - 0,6\%), портит людей (1 reakcja - 0,2\%); odpowiedzi niemieckie - Gier (3 reakcje $-0,6 \%)$, Geiz (1 reakcja - 0,2\%), Leben verderben (1 reakcja - 0,2\%), unehrlich (1 reakcja - $0,2 \%)$.

Ta część konceptu, podobnie jak pozostałe jego elementy o charakterze ewaluacyjnym, wychodzi wprawdzie poza ramy definicyjne pojęcia, lecz standaryzowana jest przez obecne we wszystkich badanych językach odnośne jednostki paremiczne, takie jak na przykład: polskie — Gdzie jest bogactwo, tam jest lajdactwo; Bogactwa przybywa, cnoty ubywa; rosyjskie — Богатство - скор путь во зло; Бедность учит, а богатство портит; niemieckie - Ein reicher Bauer kennt seine Verwandten nicht; Geld schließt die Hölle auf.

W zasobach paremicznych znajdują się również kolejne elementy konceptu, mianowicie werbalizacje źródeł i sposobów bogacenia się, przede wszystkim podkreślana w odpowiedziach polskich studentów praca (Praca wzbogaca; Arbeit und Sparen macht reiche Knechte); porównaj na przykład: polskie — praca (19 wskazań - 3,8\%), ciężka praca (3 reakcje - 0,6\%), pracowitość (1 reakcja - 0,2\%); ros. - работа (3 reakcje - 0,6\%), труд (2 reakcje - 0,4\%), заработать ( 1 reakcja - 0,2\%); niemieckie - Arbeit (3 reakcje - 0,6\%), Job (1 reakcja $0,2 \%)$, muss man sich erarbeiten ( 1 reakcja - $0,2 \%$ ).

Osiągnięcie bogactwa, poza indywidualnym wysiłkiem, ma charakter przypadkowy - to najczęściej wygrana w grze losowej lub spadek; porównaj na przykład: asocjaty polskie - lotto (3 reakcje - 0,6\%), Totolotek (2 reakcje - 0,4\%), szczęśliwy traf (1 reakcja - 0,2\%); asocjaty rosyjskie - завещание (1 reakcja - 0,2\%), передается по наследству (1 reakcja - 0,2\%), случаетcя (1 reakcja - 0,2\%); asocjaty niemieckie - Lotto (2 reakcje - 0,4\%), Erbe ( 2 reakcje - 0,4\%), kommt aus dem Nichts ( 1 reakcja - 0,2\%).

Poza jądrem dyferencjacji semantycznej konceptualizowanej jednostki w obrębie aktualności badanego pojęcia oraz silnie zindywidualizowanym subiektywnym obszarze konotacyjnym mieści się ostatnia grupa pozyskanych skojarzeń - wzorce osobowe i kulturowe bogactwa; porównaj na przykład: polskie — Bill Gates (3 reakcje — 0,6\%), Rydzyk Tadeusz (2 reakcje — 0,4\%), poset do parlamentu (1 reakcja - 0,2\%); rosyjskie — олигархи (3 reakcje 0,6\%), Абрамович (1 reakcja - 0,2\%), предприниматель (1 reakcja - 0,2\%); 
niemieckie — Bill Gates (2 reakcje - 0,4\%), König (1 reakcja - 0,2\%), Promis (1 reakcja $-0,2 \%)$.

Podsumowując, na konceptualizację bogactwa ma wpływ wiele czynników. Po pierwsze, inercja tradycyjnej kultury, przejawiająca się w odwoływaniu się użytkowników języka do tekstów precedensowych oraz historycznie ukształtowanych i przyswajanych w procesie socjalizacji wzorów myślenia i percepcji rzeczywistości. Znajduje ona wyraźne potwierdzenie między innymi w analogiach konceptu analizowanego pojęcia generowanego w wyniku testu swobodnych skojarzeń i konceptu utrwalonego w zasobach językowych istotnych z punktu widzenia poznawania oraz oswajania otaczającego świata, mianowicie paremiach i frazeologizmach. Po drugie, zjawisko dyfuzji kulturowej, to jest przenikania się i wzajemnego uzależniania wielu heterogenicznych kultur, będące wynikiem oddziaływania współczesnych mediów, globalizacji i związanych z nią procesów społecznych, przede wszystkim wzrostem mobilności i migracją. Po trzecie, bieżące doświadczenia i praktyka społeczna, wywierające mniejszy lub większy wpływ na modyfikację, względnie aktualizację, określonych elementów konceptu. Wreszcie, indywidualne przeżycia i doznania jednostki, po części również implikujące rozumienie badanego pojęcia.

\section{Bibliografia}

Anusiewicz J., Lingwistyka kulturowa. Zarys problematyki, Wydawnictwo Uniwersytetu Wrocławskiego, Wrocław 1995.

Galton F., Psychometric Experiments, „Brain. A Journal of Neurology” 1879, nr 2.

Rodziewicz B., Wartości. Polacy - Rosjanie - Niemcy, Volumina.pl, Szczecin 2014.

Siek P., Bogactwo. Przyczynek do katolickiego ujęcia tej kategorii, „Annales. Etyka w Życiu Gospodarczym"18, 2015, nr 2.

Гурочкина А.Г., Этнокультура и языковое сознание, [w:] Филология и культура: Материаль ІІІ Международной научной конференции 16-18 мая, 2001, cz. 3, Изд-во ТГУ im. Г.Р. Державина, Тамбов 2001.

Караулов Ю.Н., Филиппович Ю.Н., Лингвокультурное сознание русской языковой личности. Моделирование состояния и функиионирования, Азбуковник, Москва 2009.

Тарасов Е.Ф., Актуальные проблемы анализа языкового сознания, [w:] Языковое сознание и образ мира, red. Н.В. Уфимцева, Институт языкознания РАН, Москва 2000. 


\section{If I were a rich man... The wealth concept} as a axiological unit in the language awareness of Poles, Russians and Germans

Summary

The present article is an attempt at establishing a way of understanding the term 'wealth' as well as characterizing all the phenomena the term encompasses in communities of Polish, Russian and German students. The author analyses the results of a verbal association test.

Keywords: wealth, axiology, language awareness, verbal association test, comparative linguistics

\section{Скажем, будь я Ротиильд... Богатство как аксиологическая единица в языковом сознании поляков, русских и немцев}

Резюме

В настоящей статье определяется способ понимания понятия богатство современными польскими, русскими и немецкими студентами в аксиологическом аспекте. Автор анализирует результаты теста вербальных ассоциаций.

Ключевые слова: богатство, аксиология, языковое сознание; тест вербальных ассоциаций, конфронтативная лингвистика 